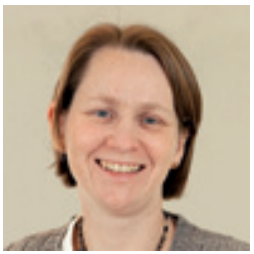

\title{
Natur innendørs
}

\section{Vårt levesett legger opp til at vi må til- bringe mye tid innendørs. Kan planter bidra til et godt innemiljø?}

For et drøyt år siden trillet min forskerkollega og jeg inn 26 potter på hjul med tropiske og subtropiske planter inn på Røros rehabiliteringssenter. Vi skulle undersøke omgivelsenes betydning for et korttids rehabiliteringskurs og ønsket å endre omgivelsene med planter. Litt av en jobb for skrivebordsakademikere, men vi, eller rettere sagt plantene, ble veldig godt mottatt. Pent å se på, kanskje, noe å snakke om, fascineres over og beundre. Der og da ble plantene et samtaletema, og vi fikk mange gode råd og meninger om alternative plasseringer.

Naturen kan hentes inn på flere måter, enten gjennom vindusutsikt til vegetasjon, bilder med naturmotiv eller ved bruk av inneplanter. En doktorgradsstudie fra Universitetet for miljø og biovitenskap fra 2007 avdekket at i undersøkte kontorlokaler var det fem ganger så mange inneplanter og tre ganger så mange bilder med naturmotiv ved arbeidsplasser uten vindu sammenliknet med plasser ved vinduer. Det kan se ut til at vi kompenserer for manglende vindusutsikt ved å bringe inn naturelementer. Evalueringen av planteintervensjonen på Røros viste også at våre 26 potter med en $1 / 2-1 \quad 1 / 2$ meter høye planter i fellesrommene ikke var for mye, men passe.

Miljøpsykologer har siden 1960-årene arbeidet med naturens betydning for menneskers evne til å hente inn igjen oppbrukte mentale krefter. En parallell teori sier at naturelementer i omgivelsene gjør at vi raskere henter oss inn etter en stressende opp- levelse. Rachel og Stephen Kaplan ved University of Michigan har lenge arbeidet med betydningen av naturmiljø for mennesker. De hevder at utsikt til naturen fra vinduet kan gi «minirestorative» opplevelser når vi er i en situasjon der vi ikke har mulighet til å være ute. Er en inneplante like restorativt som en grønn utsikt fra vinduet? Det er et begrenset antall studier av inneplantenes betydning for mennesker. I den nevnte doktoravhandlingen ble det $\mathrm{i}$ en undersøkelse også funnet små, men statistiske signifikante sammenhenger mellom planter i synsfeltet og egenrapportert reduksjon i korttidssykefravær og økt produktivitet. Det er også eksperimentelle studier som peker på en psykologisk nytteverdi, men forskningsfeltet er veldig ungt. Interessant er det at det kan være kjønnsforskjeller kvinner reagerer mer positivt på planter enn menn. På ett utfallsmål er studiene imidlertid entydige - det kan se ut som om naturelementer i form av planter eller utsikt til vegetasjon øker toleransen for smerte.

Et tilleggselement med plantene er deres betydning for luftkvaliteten. NASA publiserte i 1980-årene data som viser at planter, eller rettere sagt mikrobene $\mathrm{i}$ jorden, har evne til å fjerne flyktige organiske komponenter (VOC) i luft. I store romvolumer, som på Røros rehabiliteringssenter, har det liten betydning, men det spennende er at kursdeltakerne faktisk tenderte til å evaluere luftkvaliteten til å være bedre etter at plantene var kommet på plass. Altså påvirker plantene, som en del av de visuelle omgivelsene, hvordan vi oppfatter luftkvaliteten. Interessant er det også at Fjeld og medarbeidere i en norsk studie fra 1990-årene fant at kontoransatte klaget mindre over inneklimarelaterte helseplager der det var planter enn der det ikke var noen. Her var romvolumene mindre og plantene var plassert nær arbeidspulten, slik at både plantenes betydning for den fysiske luftkvaliteten og den psykologiske komponenten kan bidra til forklaring av funnene.

Det er viktig at bygninger og utearealer bygger på prinsippet om universell utforming, så også når det gjelder planter og allergi og overfølsomhet for duft. Norges Astma- og Allergiforbund har arbeidet med anbefalinger om allergivennlige plantearter. Det er viktig å lytte til brukerne, da tidligere negative erfaringer uansett kan gjøre planter til en negativ opplevelse.

Professor Stephen Kellert ved Yale University er opptatt av «biophilic design». Konseptet legger vekt på å skape restorative omgivelser i bygninger, samtidig som man bygger energieffektivt og skåner det ytre miljøet. Kellert argumenterer for at enkle symboler på natur også kan ha betydning i ellers bebygde omgivelser. Han er en av dem som hevder at mennesker er tilpasset et liv i naturomgivelser, og at det er grunnen til at vi reagerer positivt på naturelementer.

Innemiljøer er komplekse, og det er opplagt at små enkeltobjekter som en plante eller et naturbilde ikke løser alle utfordringer. Imidlertid er det viktig at vi ved planlegging av bygninger og innearealer innpasser positive visuelle objekter og gir arealene en utforming som bidrar til restorative opplevelser og overskudd til å håndtere daglige situasjoner, det være seg $i$ et kontormiljø eller i en helseinstitusjon.

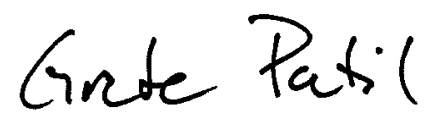

\section{I neste nummer:}

Landsstyrenummeret

Spesialistutdanningen

Storcellet granulær lymfocytt-leukemi
Samhandlingsreformen

- Luftambulansens pålitelighet

Insulinpumpe 